\title{
Glycyrrhiza lepidota Root
}

National Cancer Institute

\section{Source}

National Cancer Institute. Glycyrrhiza lepidota Root. NCI Thesaurus. Code C87564.

The dried root of Glycyrrhiza glabra, a legume native to southern Europe and parts of Asia. Licorice root contains glycyrrhizin that is hydrolyzed to the main sweet component glycyrrhetic acid. 